\title{
Administrasi Kurikulum
}

\author{
Nofita Sari \\ E-mail \\ nofitasari91199@gmail.com \\ Universitas Negeri Padang
}

\begin{abstract}
Abstrak
Adminitrasi kurikulum berfungsi sebagai alat untuk pencapaian tujuan pendidikan, apabila tujuan pendidikan berubah maka maka secara otomatis kurikulum juga harus dirubah. Bagi anak kurikulum berguna sebagai alat untuk mengembangkan segenap potensi-potensi yang dimilikinya ke arah yang lebih baik di bawah bimbingan guru di sekolah. Bagi guru kurikulum berfungsi sebagai pedoman dan acuan dalam penyelenggaraan pembelajaran di sekolah.
\end{abstract}

Kata Kunci : Kurikulum, Administrasi

\section{BAB I PENDAHULUAN}

Administrasi Kurikulum Merupakan Komponen Yang Sangat Penting Dalam Menentukan Penyelenggaraan Pendidikan, Kurukulum Bertujuan Untuk Mencapai Pendidikan. Pengembangan diri merupakan kegiatan pendidikan untuk mengembangkan kemampuan dalam bidang administrasi.Ilmu pengetahuan dan keterampilan yang dilaksanakan bertujuan dalam jangka panjang yaitu agar tenaga administrasi maupun mengembangkan ilmu yang telah dipelajari dan dipraktekkan di sekolah.

Administrasi sangat diperlukan bagi kelangsungan proses belajar mengajar dalam dunia pendidikan. Semua itu tidak lepas dari keaktifan orang-orang yang menguasai administrasi dalam sekolah. Orang sering menganggap enteng

Adminis.trasi tersebut, padahal kalau administrasi dipegang sama orang-orang yang kurang terampil maka administrasi tersebut akan berantakan. Orang yang memegang administraasi adalah orang yang sudah terlatih dalam bidangnya (orang yang sudah mendapat ilmu/ pelatihan).

Administrasi tidak hanya dalam hal keuangan saja tetapi juga dalam kerapian/ keteraturan kita dalam pembukuan.Administrasi tidak hanya dilakukan dalam waktu tertentu saja tetapi setiap hari secara kontinyu. Administrasi adalah upaya menjadikan kegiatan kerja 
sama antara guru dan karyawan agar proses belajar mengajar lebih efektif.[1]

\section{BAB II TEORI DAN PEMBAHASAN}

\section{A. Pengertian administrasi kurikulum}

Administrasi

Kurikulum

merupakan suetu komponen yang sangat prnting dan menentukan dalam penyelenggaraan pendidikan

Kurikulum berfungsi sebagai alat untuk pencapaian tujuan pendidikan, apabila tujuan pendidikan berubah maka maka secara otomatis kurikulum juga harus dirubah. Bagi anak kurikulum berguna sebagai alat untuk mengembangkan segenap potensipotensi yang dimilikinya ke arah yang lebih baik di bawah bimbingan guru di sekolah. Bagi guru kurikulum berfungsi sebagai pedoman dan acuan penyelenggaraan pembelajaran di sekolah.

(Hasan 1988) menyatakan pendapatnya bahwa konsep kurikulum di tinjau dari 4 sudut:Kurikulum sebagai suatu ide yang dihasilkan melalui teoriteori dan penelitian

1. Sebagai suatu rencana tertulis yaitu sebagai perwujudan dari kurikulum sebagai suatu ide, didalamnya berisi tentang tujuan bahan ajar, aktifitas balajar, alat-alat atau media, dan waktu pembelajaran.
2. Sebagai suatu kegiatan, merupakan pelaksanaan dari kurikulum sebagai suatu rencana tertulis yakni dalam bentuk praktek pembelajaran.

3. Sebagai suatu hasil, yaitu konsekuensi dari kurikulum sebagai suatu kegiatan, melalui ketercapaian tujuan kurikulum terhadap pesrta didik.

\section{B. Proses Administrasi Kurikulum}

Menurut (Ladjid : 2005) Ada beberapa proses administrasi kurikulum sebagai berikut :

1. Perencanaan

Perencanaan kurikulum adalah suatu pekerjaan yang memerlukan keahlian maka dari itu dikerjakan oleh para ahli atau expert dalam bidangkurikulum.sehingga

Pelaksanaan kurikulum

2. Pelaksanaan

Keberhasilan kurikulum dapat diukur dari sejauh mana siswa dapat menguasai materi yang tertuang di dalam kurikulum.

3. Pengawasan/pengembangan

Kurikulum Dalam pengembangan kurikulum terdapat dua proses utama, yaitu pengambanagan pedoman kurikulum dan pengembanang pedoman instruksional.

4. Evaluasi 


\begin{abstract}
Langkah terakhir dalam pengembangan kurikulum adalah evaluasi. Evaluasi adalah proses yang berkelanjutan di mana data yang terkumpul dan dibuat pertimbangan untuk tujuan memperbaiki sistem, Evaluasi dirasa sebagai suatu proses membuat keputusan, sedangkan riset sebagai proses pengumpulan data sebagai dasar pengambilan keputusan
\end{abstract}

\title{
C. Peran Guru Dalam Administrasi
}

\section{Pendidikan.}

Menurut Sri Herlina dalam diktat Profesi keguruan (2011:52)bahwa di sekolah guru berada dalam kegiatan administrasi sekolah. Sekolah melaksanakan kegiatannya untuk menghasilkan lulusan jumlah dan mutunya telah ditetapkan. Dalam lingkup administrasi sekolah inilah peran guru sangat penting. Oleh karena itu semua personel sekolah termasuk guru harus terlibat.

\section{Daftar Pustaka}

Hasan, Hamid. 1988. Kurikulum dan Pembelajaran. Jakarta : Bina Aksara.

Ladjid hafni. 2005. Pengembangan kurikulm menuju kurikulum berbasis kompetensi. Jakarta: Quantum Teaching 
